\author{
O. Shinkaryuk, \\ PhD (Economics), \\ ORCID 0000-0002-3004-0404,
}

V. Stolyarova,

PhD (Economics),

ORCID 0000-0002-9483-5126,

Institute of Physical Economy named after S.A. Podolynskyi, Kyiv

\title{
CONCEPTUAL PROVISIONS OF BUDGET FEDERALISM IN THE UNITARY STATE UKRAINE
}

Introduction. In the 2015 National Report «Policy of Integration of Ukrainian Society in the Context of Challenges and Threats of Events in the Donbass» (edited by E. M. Libanova) was emphasized the need to «define in the Budget Code of Ukraine the responsibility of budget spending units for late and incomplete financing». The main thing here is to determine the completion of the natural-material and cost cycle of reproduction processes at the regional and local levels $[1,2]$.

Twelve years ago (in 2008), two books on finance were published by the public organization «Znannya» in Kyiv on the recommendations of the Ministry of Education and Science of Ukraine, which contained two identical sections «Local Finance. Budget Federalism and Financial Equalization».

The first book is a textbook «Finance. Course for financiers» which was prepared by specialists of Kharkiv State University of Food Technology and Trade of the Ministry of Education and Science of Ukraine, edited by Ph.D. in Economics, Professor V.I. Osipov.

The second book is a textbook dedicated to the 40th anniversary of Ternopil National Economic University of the Ministry of Education and Science of Ukraine, edited by Doctor of Economic Sciences, Professor S.I. Yuriy, Doctor of Economic Sciences, Professor V.M. Fedosov.

For ten years monographic studies contributed to the development of the provisions of budget federalism. They were provided by passports of the master's educational program 8.03050801 «Finance and Credit» and the scientific specialty for candidate and doctoral dissertations in the specialty 08.00 .08 «Money, Finance and Credit».

So, without disclosing the contents of the same chapters of these books, we state that they coincide with the following author's concise definition of budget federalism in the unitary state. Its essence is to regulate such scales of financial self-sufficiency of regional authorities and local governments on the assessment and forecast calculations of sources and volumes of local finances with the use of budget and fiscal decentralization of revenues, which are determined on the basis of expenditure powers in socio-economic development.

Problem statement. Expenditure powers should correspond to the volumes fiscal revenues. Regional authorities and local governments independently analyze options for their own financial capabilities in the base, reporting and planning periods (at least in three-year terms) without expecting instructions and control figures from national authorities. On the basis of social norms (not lower than the level of minimum social needs and sectoral standards for providing services to the population - educational and medical subventions, funds for social protection and social security) they independently decide on the implementation of Local Target Programs and Action Plans of Regional Strategies.

The introduction of budget federalism is aimed, on the one hand, at meeting the financial needs of each territorial community in accordance with its economic capacity with the mobilization of intraregional reserves, and on the other, - at ensuring social equality in obtaining constitutionally guaranteed public services in each district.

But, unfortunately, the provisions of budget federalism were not realized by the assistants of the people's deputies and heads of the Verkhovna Rada of Ukraine and the Government, specialists of the Ministry of Finance of Ukraine, the Ministry of Economic Development of Ukraine and the Ministry of Education and Science of Ukraine for their practical use.

Nine years ago (in 2011) the State Educational and Scientific Institution «Academy of Financial Management» and the Ukrainian University of Finance and International Trade of the Ministry of Finance of Ukraine published a scientific publication of the team of authors «Scientific and Practical Commentary to the Budget Code of Ukraine» (ed. F.O. Yaroshenko, scientific editor - responsible executor of the project V.F. Stolyarov).

In the Foreword, it was proposed to include in the financial standards of budget security in the planning of local budget expenditures (public administration; education; health care; social protection and social security; 
culture and art; physical culture and sports) additionally financial standards for budget provision of guaranteed housing and communal services and mass media (to Chapter 13 «General Provisions», in the article «Financial standards of budget provision»).

In addition, it was recommended to develop in the Foreword the «Basic provisions for the implementation of the responsibility of higher state and local authorities and local governments for underfunding under the budget standards of national and regional human development programs» (to Section V «Control over compliance with budget legislation and liability for violations budget legislation»).

The purpose of the article. These proposals and recommendations should be aimed at establishing financial standards for budgeting of social services from the needs specified by law, and not from the amount of financial resources that the Ministry of Finance of Ukraine together with the Main managers of budget funds for educational and medical subvention, social protection and social provision consider it possible to allocate to meet these needs.

Outline of the main results and their justification. The main scientific and applied result of the Khmelnitsky Regional State Administration Working Group on the implementation of the Forecasting-Programming-Budgeting (FPB) system in the activities of regional state administrations was the pilot project «Mechanism of state regulation of regional human development of the administrative region in the conditions of decentralization», which gave grounds to the head of the Khmelnitsky Regional State Administration Working Group O.O. Korniichuk to address to the Government with proposals to conduct in 2017-2021 a corresponding experiment in the region «State regulation of regional human development at the level of administrative region» (by analogy with conducting from 01.04.2001 to 01.04.2005 state and legal experiment of local government development in the city of Irpin in the villages of Bucha, Vorzel, Gostomel, Kotsyubynske of Kyiv region) [4].

The main purpose of the experiment was to work out and finalize the powers of regional state administrations and the state administrations (functions and structure, rights and responsibilities, competencies in relation to local governments) in the conditions of realization of the Concept of local government reform and territorial organization of government and relevant laws of Ukraine on budget and financial decentralization using social standards (in descriptive and cost form with regulation of their $\min / \mathrm{max}$ values within the amount of financial resources) and industry standards for the provision of services in the field of sustainable human development of the region as a central link of its sustainable (environmental and social) operation and dynamic development.
Regional state administrations should monitor compliance with the size of the financial standard of budget provision of public services, taking into account the various features of the population of each territory and its moral principles: spirituality and education, historical heritage and ethnic values, customs and traditions, culture and worldview, peaceful mentality and territorial unity.

In case of identified deviations - to have the right to receive additional transfers and subsidies from the State Budget of Ukraine, as well as to use part of the funds from the public-private partnership in the region, sponsorship and donor, international technical and financial assistance, and various grants with participation of the diaspora for achievement of financial standards provision of public services in the administrative and territorial boundaries of the region.

In the conditions of the experiment it was planned to improve methodological support of formula calculations of subventions, subsidies and transfers in region based on the fact that the so-called adjustment coefficients would be determined by the Khmelnitsky Regional State Administration relative to the average values of the relevant indicators of the united territorial communities (UTCs) and districts of the region, and not relative to the average values of the relevant indicators in Ukraine as a whole [4].

One of the main results of the experiment would be to take into account local features in the formation of the Registers of the following indicators of the system of state regulation of regional human development:

- state standards of social services and the procedure for determining the needs of the population of administrative and territorial units and monitoring and evaluation of their quality;

- industry norms and standards of service provision, primarily in the fields of education, health care and social protection of the population;

- social norms for each of the powers delegated by the state to local governments on the basis of the average administrative and territorial unit in descriptive and cost form $(\mathrm{min} / \mathrm{max})$, taking into account the amount of own and additional necessary financial resources in the context of decentralization.

The creation of these registers would ensure the development of basic provisions for the implementation of legal responsibility of state and regional authorities and local governments for underfunding the budget provisions of the National Human Development Program and Regional Human Development Programs.

In turn, this would facilitate the transition from an administrative and command mechanism of budget unitarism to the administrative and contractual interaction of public authorities at different levels of government based on the legal determination of independence and depth of compatibility of budget centralism with budget federalism. 
The first basic aspect of human development is the «reproduction of the population». Therefore, first of all, socially adequate management of regional human development should be aimed at achieving harmonious symmetry and balance in the hierarchy and dynamic synchronization in the time of territorial and national reproductive processes of human capital.

It is possible and expedient to ensure harmonization of reproductive processes of the population with the use of the proportions of the «Golden Intersection» in the established reference ratios of volumes and dynamics of funds from the state and local budgets (including funds of local governments and the UTCs) for human development.

According to the proportions of the «Golden Intersection», the ratio of funds for human development from the state and local budgets to the amount of funds from the state budget should be equal to the ratio of the state budget funds from the local budgets and make up the golden proportion, which is 1.618 .

The proportions of the "Golden Intersection», which are $62 \% \times 38 \%$ (where $62 \%$ is the main and $38 \%$ - the additional value), determine the boundaries of the trajectory of sustainable human development of the adjacent scales of the administrative and territorial structure.

In the hierarchical system of public service management, the upper limit of this trajectory of sustainable human development (the limit of budget federalism) is determined by the ratio of $62 \%$ of the local budget to $38 \%$ of the state budget funds.

The lower limit of the trajectory of sustainable human development (the limit of budget centralism) is determined by the ratio of $62 \%$ of funds from the state budget to $38 \%$ of the local budget funds (100\% of funds from the state budget is budget unitarism).

The common boundaries of budget centralism and budget federalism, which reflect the level of autonomy and depth of interaction of national and territorial processes of human capital reproduction, thus form a decision-making area in social dialogue of national and regional authorities of adjacent levels of hierarchy government $24 \%(62 \%-38 \%)$ of the total amount of budget funds for human development in the region $(100 \%$ is a consolidated budget as the sum of funds from the state and local budgets).

Due to this approach, the cost options of project decisions of Action Plans for the implementation of the State and Regional Development Strategies, as a form of expression of own and common interests of related scales, should be in the social dialogue of the adjacent levels of public administration to achieve coherence in co-financing of human development processes.

The two-sector model of market economy developed in the early 1990s by the ENDI of the State Plan of Ukraine and provided for use of harmonious proportions of the «Golden Intersection» to determine the ratio of public and private property of a diversified national economy and the splitting of national and local taxes.

The proportions of the «Golden Intersection» should be used to optimize the structure of the consolidated regional budget in determining the amount of budget funds of administrative districts, local governments and the united territorial communities.

The implementation of the ideas and provisions of budget federalism in Ukraine as a unitary state during of the pilot project will contribute the determine scales of financial self-sufficiency of Luhansk and Donetsk regions according to the Minsk Agreements of 2014.

At the initial stage of practical implementation of the idea of budget federalization, it would be appropriate to transfer all administrative districts simultaneously, without establishing a special status for some of them.

At the next stage, it would be expedient to transfer the considered administrative and territorial territories to the conditions of budget federalization, and at the final stage - local governments and the united territorial communities.

Conclusions. The logic of budget federalization is aimed at preserving the territorial integrity of Ukraine as a unitary state with a parliamentary and presidential form of government and administration. The two-tier budget system (state budget - local district budgets, local governments and the united territorial communities) should become the financial basis of the new administrative and territorial structure of Ukraine, which will not lead to a situation when the leadership (those in power), which are always right, but can't «manage in a new way", and the masses which are always guilty, but don't want to «live the old way».

The analytical assessment of social standards and regulations, as well as sectoral norms for the provision of social services (primarily in the field of education, medicine and social protection of the population) within administrative districts and regions should be the authority of district and regional state administrations.

The average quantitative values of social norms and industry standards, of course, will differ from the average values of similar indicators for Ukraine as a whole. Therefore, the regulation of their minimum/ maximum values should take place within local financial resources.

In this regard, the development of local standards and regulations should be facilitated by the analysis and evaluation of components and the Regional Human Development Index (RHDI) at the region level with the gradual development of a national statistical database for both urban and rural settlements and the united territorial communities. Over time, this will allow us to accumulate a statistical basis for calculating the average values of the components of the RHDI using them as criteria for financial equalization of the components of human development between the subjects of the territories. 
In addition, in the future, comparative estimates of the ratios of the RHDI in administrative districts and regions, urban and rural settlements with the average RHDI values in similar territories and for Ukraine can become a criterion for the distribution of budget funds from the State and regional funds for regional development.

\section{Literature}

1. Політика інтеграції українського суспільства в контексті викликів та загроз подій на Донбасі: національна доповідь / за ред. Е.М. Лібанової. Київ: НАН України, 2015. 363 с. 2. Stolyarova V., Ovcharenko T., Kalashnikov L. Formation of budget federalism in Ukraine and features of modern Donbass. Економічнии вісник Донбасу. 2019. № 3 (57). С. 89-102. doi. 10.12958/1817-3772-2019-3(57)-89-102. 3. Корнійчук О.О., Столяров В.Ф., Шинкарюк О.В. Формування механізму державного регулювання стійкого людського розвитку Хмельницької області (від ідеї до експерименту: Ч. 1. - стан і проблеми державного регулювання). Економіка та держава. 2017. № 3 (березень). С. 4-15. 4. Корнійчук О.О., Столяров В.Ф., Шинкарюк О.В. Формування механізму державного регулювання стійкого людського розвитку Хмельницької області (від ідеї до експерименту: Ч. 2 - перспективи державного регулювання по-новому). Економіка та держава. 2017. № 4 (квітень). С. 4-15.

\section{References}

1. Libanova E. M. (Ed.) (2015). Polityka intehratsii ukrainskoho suspilstva $v$ konteksti vyklykiv ta zahroz podii na Donbasi [Policy of integration of Ukrainian society in the context of the challenges and threats of events in the Donbas: national report]. Kyiv, NAS of Ukraine [in Ukrainian].

2. Stoliarova V., Ovcharenko T., Kalashnikov L. (2019). Stanovlennia biudzhetnoho federalizmu v Ukraini ta osoblyvosti suchasnoho Donbasu [Formation of budget federalism in Ukraine and features of modern Donbass]. Ekonomichnyi Visnyk Donbasu - Economic Herald of the Donbas, 3(57), pp. 89-102. doi: 10.12958/1817-37722019-3(57)-89-102 [in Ukrainian].

3. Korniichuk O.O., Stoliarov V.F., Shynkariuk O.V. (2017). Formuvannia mekhanizmu derzhavnoho rehuliuvannia stiikoho liudskoho rozvytku Khmelnytskoi oblasti (vid idei do eksperymentu: Ch. 1 - stan i problemy derzhavnoho rehuliuvannia) [Formation of the mechanism of state regulation of sustainable human development of Khmelnitsky region (from idea to experiment: Part 1 - state and problems of state regulation)]. Ekonomika ta derzha$v a-$ Economy and the state, 3, pp. 4-15 [in Ukrainian].

4. Korniichuk O.O., Stoliarov V.F., Shynkariuk O.V. (2017). Formuvannia mekhanizmu derzhavnoho rehuliuvannia stiikoho liudskoho rozvytku Khmelnytskoi oblasti (vid idei do eksperymentu: Ch. 2 - perspektyvy derzhavnoho rehuliuvannia po-novomu) [Formation of the mechanism of state regulation of sustainable human development of Khmelnitsky region (from idea to experiment: Part 2 - prospects of state regulation in a new way)]. Ekonomika ta derzhava - Economy and the state, 4, pp. 4-15 [in Ukrainian].

Столяров В. Ф., Шинкарюк О. В., Столярова В. В. Концептуальні положення бюджетного федералізму в унітарній державі Україна

У статті в порядку постановки проблеми визначено вихідні концептуальні положення бюджетного федералізму у взаємодії з бюджетним централізмом.

Розкрито основні ідеї й задуми проведення пілотного проекту «Державне регулювання регіонального людського розвитку в адміністративній області» (на прикладі Хмельниччини).

Розглянуто права та відповідальність (основні повноваження) обласних державних адміністрацій та обласних рад у регулюванні обсягів і структури місцевих бюджетів на фінансування складових Індексу регіонального людського розвитку.

Фінансову самодостатність регіональних та місцевих органів влади, органів місцевого самоврядування та об'єднаних територіальних громад регламентовано видатковими повноваженнями в межах фіскальних надходжень до місцевих бюджетів.

Розглянуто співвідношення бюджетних коштів місцевого і державного рівнів у Зведеному бюджеті України, які будуються на основі гармонійних пропорцій «Золотого перетину».

Прямі бюджетні трансферти пропонується здійснювати за нормативами фінансового забезпечення соціальних стандартів на людський розвиток.

Бюджетний федералізм в унітарній державі полягає в регламентації таких масштабів фінансової самодостатності органів регіональної влади та місцевого самоврядування щодо оцінки та прогнозних розрахунків джерел і обсягів місцевих фінансів на основі бюджетно-фіскальної децентралізації за доходами, які визначено, виходячи з видаткових повноважень у соціально-економічному розвитку.

Ключові слова: бюджетний федералізм, бюджетний централізм, бюджетний унітаризм, фінансова самодостатність, бюджетно-фіскальна децентралізація, джерела місцевих фінансів, видаткові повноваження.

Stolyarov V., Shinkaryuk O., Stolyarova V. Conceptual Provisions of Budget Federalism in the Unitary State Ukraine

The article defines the initial conceptual provisions of budget federalism in interaction with budgetary centralism in the order of the problem statement.

The main ideas and plans of pilot project «State regulation of regional human development in the administrative region» (on the example of Khmelnitsky region) are revealed.

The rights and responsibilities (main powers) of the regional state administrations and the regional councils in regulating the volume and structure of local budgets for financing the components of the Regional Human Development Index are considered.

The financial self-sufficiency of regional and local authorities, local governments and united territorial com- 
munities is regulated by expenditure powers within the limits of fiscal revenues to local budgets.

The ratios of budget funds of local and state levels in the Consolidated Budget of Ukraine, which are built on the basis of harmonious proportions of the «Golden Intersection», are considered.

It is proposed that direct budget transfers should be carried out in accordance with the norms of financial provision of social standards for human development. Budgetary federalism in a unitary state is to regulate such scales of the financial self-sufficiency of regional authorities and local governments to assess and forecast the sources and volumes of local finances on the basis of budget and fiscal decentralization of revenues, which are determined based on expenditure powers in socio-economic development.

Keywords: budget federalism, budget centralism, budget unitarism, financial self-sufficiency, budget and fiscal decentralization, sources of local finances, expenditure powers.

Столяров В. Ф., Шинкарюк А. В., Столярова В. В. Концептуальные положения бюджетного федерализма в унитарном государстве Украина

В статье в порядке постановки проблемы определены исходные концептуальные положения бюджетного федерализма во взаимодействии с бюджетным централизмом.

Раскрыты основные идеи и замыслы проведения пилотного проекта «Государственное регулирование регионального человеческого развития в административной области» (в примере Хмельницкой).
Рассмотрены права и ответственность (основные полномочия) областных государственных администраций и областных советов в регулировании объемов и структуры местных бюджетов на финансирование составляющих Индекса регионального человеческого развития.

Финансовая самодостаточность региональных и местных органов власти, органов местного самоуправления и объединенных территориальных общин регламентирована расходными полномочиями в пределах фискальных поступлений в местные бюджеты.

Рассмотрены соотношения бюджетных средств местного и государственного уровней в сводном бюджете Украины, которые строятся на основе гармоничных пропорций «Золотого сечения».

Прямые бюджетные трансферты предлагается осуществлять по нормативам финансового обеспечения социальных стандартов на развитие общества.

Бюджетный федерализм в унитарном государстве заключается в регламентации таких масштабов финансовой самодостаточности органов региональной власти и местного самоуправления по оценке и прогнозным расчетам источников и объемов местных финансов на основе бюджетно-фискальной децентрализации по доходам, которые определены, исходя из расходных полномочий в социально-экономическом развитии.

Ключевые слова: бюджетный федерализм, бюджетный централизм, бюджетный унитаризм, финансовая самодостаточность, бюджетно-фискальная децентрализация, источники местных финансов, расходные полномочия.

Received by the editors: 06.12.2019 and final form 19.12.2019 